BACTERIOLOGICAL NOMENCLATURE AND

\title{
STATUS OF PSEUDOMONAS MIGULA 1894 AS A GENERIC NAME, AND OF PSEUDOMONAS AERUUSINOSSA (SCHRÓTER) MIGULA 1900 AS TYPE SPECIES Preliminary statement - File No. 7
}

The Editorial Board has prepared the following statement for the consideration of the members of the Judicial Commission and in order to secure a preliminary ballot before a formal Opinion is prepared for final approval The Editorial Board will be pleased to receive com. ments and criticisms from any person interested

PSE JDOMONAS MIGULA 1894 was proposed as a generic name in the (1) following statement. Fseudomonas nov gen Zellen mit polaren Bewegungsorganen Endosporenbildung kommt bei einigen Arten, ist aber selt ener ( $Z$. B. FE udomonas :0 $\therefore e a$

There is no citation to a pre viously described species nor any clue as to which of the nine or more species previously de scribed and bearing the speci fic epithet is to apply Undex Rule 14 of he International Bacteriolog 1 al Code of Nomenclature the species name Fscwatmona. ia ca Migula 1894 was not val idly published and under Rule 24 the name is illegitumate. The next year Migula (1895 p 29) (2) described the genus Pandacas Migula in gieater detail He grouped the species into two sections the firs: was Eup wankno to which he allocated 11 species previous ly named by other authors. and for which he gave brief des criptions The first species named is Psoudomchas pyojacka (Gessard) Migula 1895 (Ba)

\section{(1) Miguia; $W$ Ueber exn} neues System der Bakterien Arb. Bact, Inst Karlsruhe 1. 237 ? 84 .

(2) Migula W Schizomyce tes (Bacteria Bacterien) in Engler $A$ and $K$ Prant 1 . Die naturlichen Pflanzenfami 1 ien Teil 1 Abt la 29 . $895^{\circ}$
The second species named is Psendomonas urilacea (Scnröter) Migula (Baibiws iolacews Sch. róter 1886.) (1)

FEcidomorice Migula 1894 was described as a genus without any validly described or designated species Rule 9 (Amended) of The International Code of Bacter. iological Nomenclature states

The nomenclatural type species of a genus is the species or one of the species included when the genus was originally published

Obviously if Fsewamonas Migula 1894 is to be recognized as a genus it must be associated with the names of the species designated and described by Mugula in 1895 Alternatively the generic name Pscuasmunas might be recognized as having been validly published in 1895 Migula (1000 p 884) (2) تz cognized rhat the name bed the tw wh if wehroter 1872(3) antedated $\mathrm{Ba}$. Gessard 1882 (4) and publushed the name as P.ewhonas a wg tu (Schrótes) Migula 1900

Euchanan ( $1918 \mathrm{p}$ 18) desig nated as the type specres

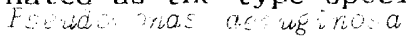

(1) Schröte: J Schizomycetes in Cohn. F. Kryptogamen Flora von Sclilesien. 3 136.174, 1886 (2). Migula, W System der Bakterien 2 884 900. (3) Schróter; J Ueber exnige durch Bacterien gebildete Pig mente in Cohn $F$ Beitráge $z$ Biologie d Pflanzen 1 


\section{INTERNATIONAL BULLETIN}

(Schroter) Nigula (1). This type designation was accepted by the Committce of the Sociery of American Bacteriologists on Characterization and Classifica tion of Bacterial Types. (2) Enlows (1920 : 24) (3) des ienated $F$. wa r r a lia a (Shoter 18S6; Higula as the bje steces by monctypy low ever Migula in 1894 (see above) gave no citation to establish the identity of Psewdimuna vio a ta. Thet fore this des ignation of the type species by Enlows is probably invalid

(1) Buchanan $\mathrm{K}$. Studies in the nomenclature and clase if 1 cation of the bacteria $V$. Singroups and gencra of the Bacteriaclae Jour Bact i 48 I. 518

This article contains a type. graphical er ror thr narie of the type srecies is $e^{i v e n ~ i n . ~}$ correcily as rendomonas ae "usinosa" (Schroter) Frost instead of Pseudomonas aeru. ginosa (rjinger) bigule. (2) Winsiow er al Jour. Bact 5.204. 2920

(3) Lnfows, Ella $M$. The generic names of bacteria. Holenic Laboratory urited States Public Healih Scrvice Ireasury Dept. Bili. $12 \mathrm{i}$ iQ20.
There are numerous older gen. eric names which include one or more species placed by Miguia 1895 in tic womorias Migula $(1895 \mathrm{p} 29)$ I 1 sts the following previously published generic names as synonyms of iscudonchas $E \bar{a}$. W n Fischer 1895 Cde th num Fischer 1895 $F$ r ian Fischer 1895. Ea Fischer 1895 Chos b hum Fischer 1895, Flentilu Fis cher 1895 a $h 06 a$ is $i$ m Fischer 1895 Other older names that nay be synonymous in whole or in part are Chi.0\%00a $60 \%$ : Guillebeau i890 chromsba lestum Eergonzini 1881, Bac se tàm Schroter $18 \% 2$.

Would stability in bacterio logical nomenclature be advanced and confusion avcided by issuance of an Opinion by the judicial Comission containing onc or more of the foilowing statements?

1 Pseudomonas Migula 1894 shail be conserved and placed in the list of genera conseevaria.

2. Feudomonas Nigula 1894 shall be associated with the desigrations and description speries given by Wijgula 1805

3. Fseudomonas ae"upinosa (Solirtyer) Migula is the type species of the genus Pseradrionas ivisula 1894 . 